Cite as: Schlacher TA, Strydom S, Connolly RM (2013) Multiple scavengers respond rapidly to pulsed carrion resources at the land ocean interface. Acta Oecologica, 48: 7-12

\title{
Multiple scavengers respond rapidly to pulsed carrion resources at the land- ocean interface
}

\author{
Thomas A. Schlacher ${ }^{* 1}$, Simone Strydom ${ }^{1}$, Rod M. Connolly ${ }^{2}$ \\ 1 Faculty of Science, Health \& Education. University of the Sunshine Coast. Maroochydore DC, Q- \\ 4558. Australia.
}

${ }^{2}$ Australian Rivers Institute - Coast \& Estuaries, and School of Environment, Griffith University, Gold Coast Campus, QLD, 4222, Australia

* corresponding author: tschlach@usc.edu.au

\begin{abstract}
Sandy beaches are the globe's longest interface region between the oceans and the continents, forming highly permeable boundaries across which material flows readily. Stranded marine carrion supplies a high-quality food source to scavengers, but the role of animal carcasses is generally underreported in sandy-beach food webs. We examined the response of scavengers to pulsed subsidies in the form of experimental additions of fish carcasses to the dune-beach interface in eastern Australia. Ghost crabs (Ocypode spp.) are the dominant invertebrate scavengers in these habitats and they responded strongly and consistently to changed resource availability: densities increased significantly within days of carrion augmentations. Carcasses added experimentally also formed local nuclei for a diversity of vertebrate scavengers that aggregated at food falls; these included large lizards, several species of birds (including raptors), and foxes. Consumption of fish carrion by the vertebrate scavengers was rapid and often complete. There is also evidence for higher-order interactions, where responses of invertebrate scavengers became depressed in plots where vertebrate scavenger activity was intense. Our findings emphasize that carrion can be a pivotal component of beach food webs.
\end{abstract}

Keywords: carrion; scavengers; ghost crabs; food webs; allochthonous inputs

\section{Introduction}

Sandy beaches of open coasts form one of the globe's largest interface regions between the sea and the land (Bascom 1980). Their long and highly permeable border with the oceans is crossed by marine matter that drifts ashore with waves, currents and tides, often forming distinct accumulations strandlines - near the dunes (Barreiro et al. 2011). These strandlines form important structural and functional component of beach ecosystems, including the provision of habitat, food and nutrients (Dugan et al. 2003; Dugan et al. 2011; MacMillan and Quijon 2012).

From an ecosystem perspective, marine organic matter deposited on beaches constitutes a critical dietary input for beach consumers (Colombini and Chelazzi 2003). The importance of such trophic subsidies is predicted to be particularly high for food webs of open-coast beaches for three principal reasons: i) beaches lack attached larger plants and in situ primary production on the unvegetated part of the beach is very low (McLachlan and Brown 2006); ii) marine matter is transported onshore by physical forces (e.g. wind, waves, currents) with little mechanical impedance (Wright and Short 1984), and iii) imported material often accumulates at the base of the foredunes, enhancing its availability as a food resource (Orr et al. 2005; Spiller et al. 2010).

Death of animals is ubiquitous and supplies ecosystems with surprisingly large numbers of animal carcasses generated by non-predation events such as disease and malnutrition (DeVault et al. 2003; Beasley et al. 2012). This rich dietary resource is exploited by a diverse, and abundant assemblage 
of scavengers (Houston 1979; Ruxton and Houston 2004). Feeding on carcasses is also more widespread than traditionally acknowledged, and channels substantial amounts of energy through many food webs (Wilson and Wolkovich 2011).

Animal carcasses are part of the spectrum of organic matter stranded on beaches and, as in other ecosystems, are predicted to constitute high-quality food sources exploited by scavengers (Wilson and Wolkovich 2011). Carrion and scavenging are well represented in the literature on sandy shores, spanning a wide taxonomic ambit from gastropods to hyenas (Brown 1982; Skinner et al. 1995). Scavenging on beaches has, however, rarely been contextualised in a broader ecological framework (sensu Beasley et al. 2012).

Fluxes of carrion and other matter between abutting ecosystems constitute important functional linkages in many landscapes (Polis et al. 1997; Schlacher and Connolly 2009). These exchanges also couple production and consumption processes across ecological boundaries, shaping the dynamics and architecture of consumer populations and recipient food webs (Spiller et al. 2010). On sandy shorelines, organic matter of marine provenance is translocated across two ecotones: first, from neritic waters and the surf-zone to the littoral and, secondly, from the littoral to coastal dunes (McLachlan 1991). Movement of material onto the beach is overwhelming by physical vectors, whereas biological vectors are usually more important in translocating marine production to terrestrial consumers and thus systems (Barrett et al. 2005; Mellbrand et al. 2011). These fluxes are largely asymmetrical, with the upland movement of marine matter being the dominant spatial trajectory (Sanchez-Pinero and Polis 2000).

The dependence of sandy-beach food webs on imports of organic matter from the sea (Heymans and McLachlan 1996), and the increasingly recognized importance of carrion and scavenging in many food webs and across ecotones (Wilson and Wolkovich 2011) have led to a conceptual understanding of food webs of open-coast beaches as containing species that have evolved to exploit high-quality carrion efficiently. We tested this prediction experimentally by manipulating the availability of a significant carrion source, fish carcasses, and measuring the response of the key scavenger, ghost crabs (Ocypode spp.).

\section{Methods}

The site for the experiment was an ocean-exposed sandy shore on North Stradbroke Island, in eastern Australia (Fig. 1). The physical habitat characteristics of the beach are typical of much of the subtropical/warm-temperate coast; i.e. intermediate morphodynamic type, waves $1-2 \mathrm{~m}, 5-80 \mathrm{~m}$ wide beach face, medium sands (Schlacher and Thompson 2007; 2008; Schlacher and Lucrezi 2010).

Carrion supply was experimentally manipulated and the numerical response of beach scavengers measured in 17 experimental plots dispersed over a $3.2 \mathrm{~km}$ long stretch of beach (Fig. 1); distance between plots was randomised within a range of 150 to $250 \mathrm{~m}$. Treatments were randomly allocated to plots, with the constraint that not more than two of the same treatment type could abut (Fig. 1). Plots measured $3 \mathrm{~m}$ (across-shore) x $10 \mathrm{~m}$ (along-shore) following Schlacher and Lucrezi (2010), with the upper edge of plots aligned with the base of the dunes.

Key habitat metrics were highly similar between treatment and control plots: there was no significant difference in mean slope values between treatments $\left(P=0.39\right.$, Control: $3.8 \pm 0.8^{\circ}$; Treatment: $\left.2.9 \pm 0.7^{\circ}\right)$, in mean grain size $(P=0.92$; Control: $280 \pm 5 \mu \mathrm{m}$; Treatment: $279 \pm 5 \mu \mathrm{m})$, or in other sediment statistics (sorting: $P=0.42$, skewness: $P=0.19$, kurtosis: $P=0.35$ ). We therefore consider it highly improbable that outcomes of the experiment were confounded by systematic habitat differences between treatments. 


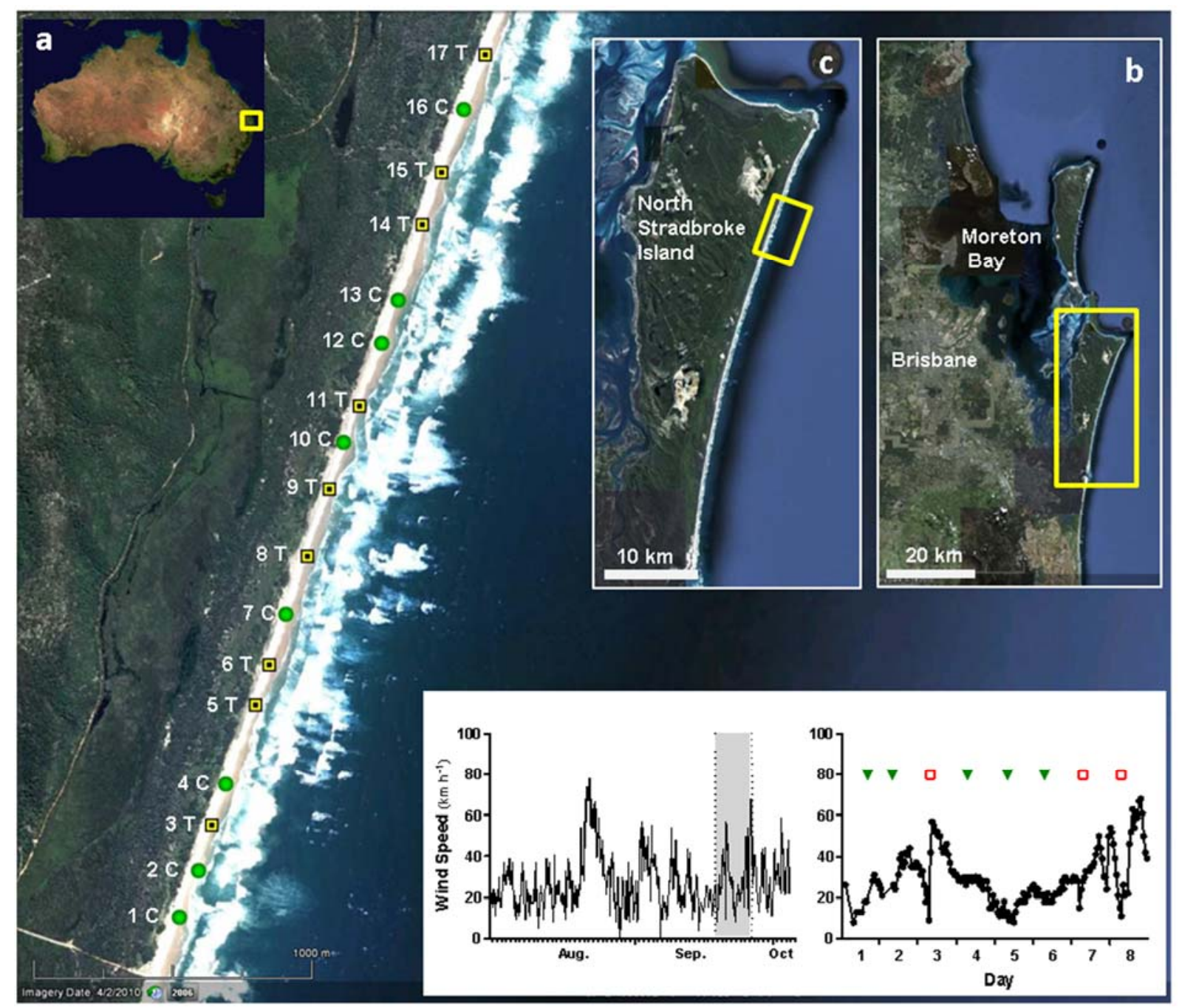

Fig.1 Location of the experiment in eastern Australia (a) on the ocean-exposed beach of North Stradbroke Island $(c, b)$. Main panel shows spatial arrangement of treatment (squares) and control plots (circles). Size of plots not to scale, being $3 \mathrm{~m} \times 10 \mathrm{~m}$. Insert shows wind speeds recorded in the preceding weeks (left panel) and during the experiment. Green arrows: successful burrow counts of ghost crabs; red squares: data discarded on days with strong winds that obliterated burrows.

Carrion was added to the treatment plots in the form of flathead mullet, Mugil cephalus. The fish were caught locally in the surf zone by a commercial fisher. They measured $36 \mathrm{~cm}(\mathrm{TL}, \bar{x}=36.4 \mathrm{~cm}$, se $=0.33, \mathrm{n}=30$ ) and weighed about $500 \mathrm{~g}$ (wet weight, $\overline{\mathrm{x}}=499 \mathrm{~g}, \mathrm{se}=9.4, \mathrm{n}=30$ ) and three fish were added to each of the $3 \times 10 \mathrm{~m}$ treatment plots per day. To achieve greater dispersion of carrion across the plots, each fish was cut into three approximately equal-sized pieces which were scattered haphazardly across the plot, and carrion addition was thus about $1,500 \mathrm{~g}$ per day in the form of nine fish pieces. The experiment was conducted over 7 days in the austral summer, from 19 to 26 Sep. 2011. On Day 1, before any manipulation of carrion, sediment samples (three cores per plot) were taken from each plot and the angle of the beach face measured following standard beach survey methods (see Schlacher et al. 2008). Thereafter, carrion was added to the treatment plots (Fig. 1), approximately two hours before sunset, every day for a week. Every morning, within two hours of sunrise, we measured the following variables in each plot: i) number and opening diameter of ghost 
crab burrows (see below), ii) number of carrion pieces remaining, and iii) presence of vertebrate scavengers (foxes, birds) or their tracks.

The primary ecological response to carrion augmentation that we measured was the density of ghost crabs. Crab density was quantified via counts of burrow openings on the beach surface, which has become the standard method for abundance estimates in this group of organisms (Schlacher et al. 2011; Noriega et al. 2012). Two species of ghost crabs, Ocypode ceratophthalma and Ocypode cordimana occur on the beach, but their burrow openings cannot be distinguished with confidence. We therefore report all burrow counts at the genus level (see Schlacher et al. 2007). Strong winds (i.e. $>40 \mathrm{~km} \mathrm{~h}^{-1}$ ) on days 2, 7 and 8 obliterated burrow openings and hence these dates were excluded from the numerical analysis.

\section{Results}

\subsection{Invertebrate scavengers}

Ghost crab scavengers responded rapidly and strongly to enhanced carrion supply on the beach (Fig. 2; GLM: Day x Treatment $F_{(4,75)}=7.80, P<0.001$ ). On day 4 , after 3 experimental augmentations of fish carcasses, densities of ghost crabs had increased, on average by $45 \%$ and were significantly higher in carrion-treatments than control plots (Fig. 2; $P=0.034$ ). Densities of the scavengers continued to increase thereafter, being $75 \%$ higher on day $5\left(\Delta_{\text {control/treatment }}=1.75 \pm 0.19\right)$, and more than double on day 6 of the experiment $\left(\Delta_{\text {control/treatment }}=2.13 \pm 0.27\right)$. Conversely, in control plots without experimental food augmentations, crab densities changed comparatively little or declined over the course of the experiment (Fig. 2).

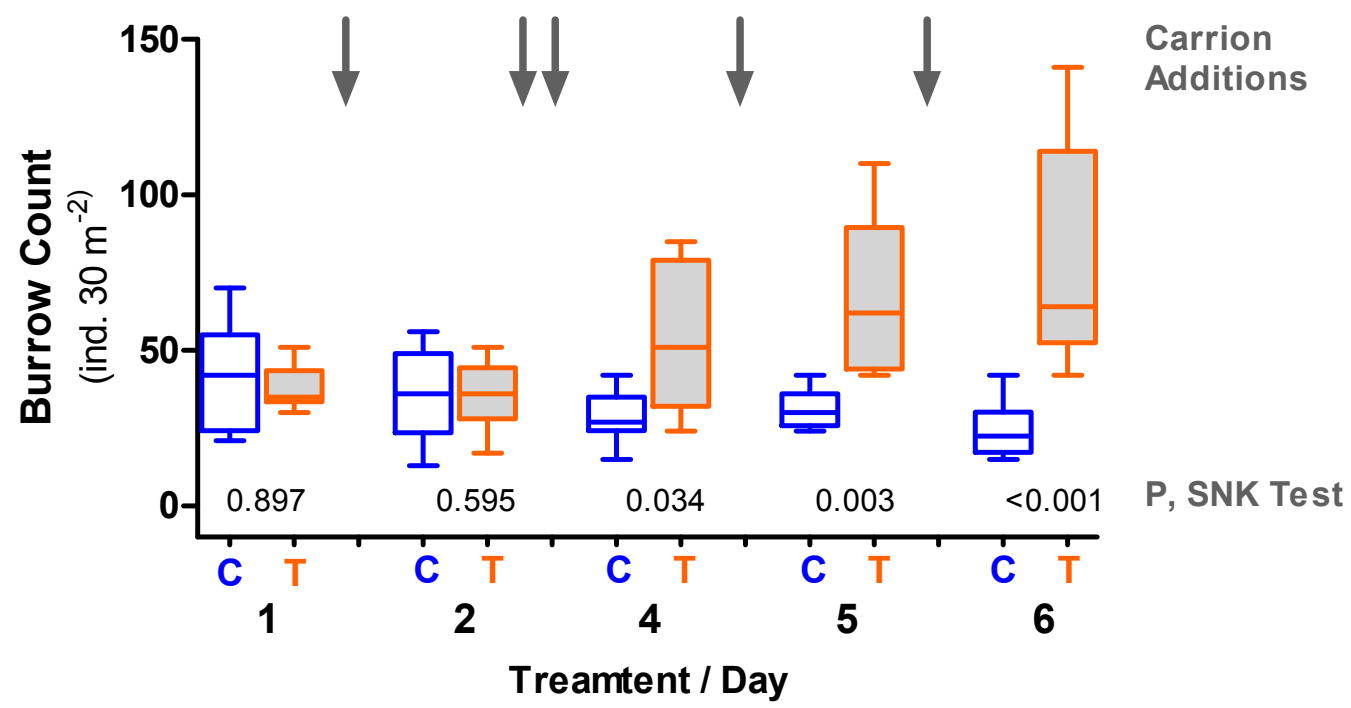

Fig. 2. Effect of pulsed carrion additions on the density of ghost crabs in plots at the base of dunes. The experiment ran for 6 days with carrion (mullet, Mugil cephalus) added to plots on 5 days. $C=$ control plots (open bars), $T=$ treatment plots (shaded bars). $P$ values refer to pairwise comparisons (using SNK test) following a significant Time $x$ Treatment interaction term in ANOVA. 


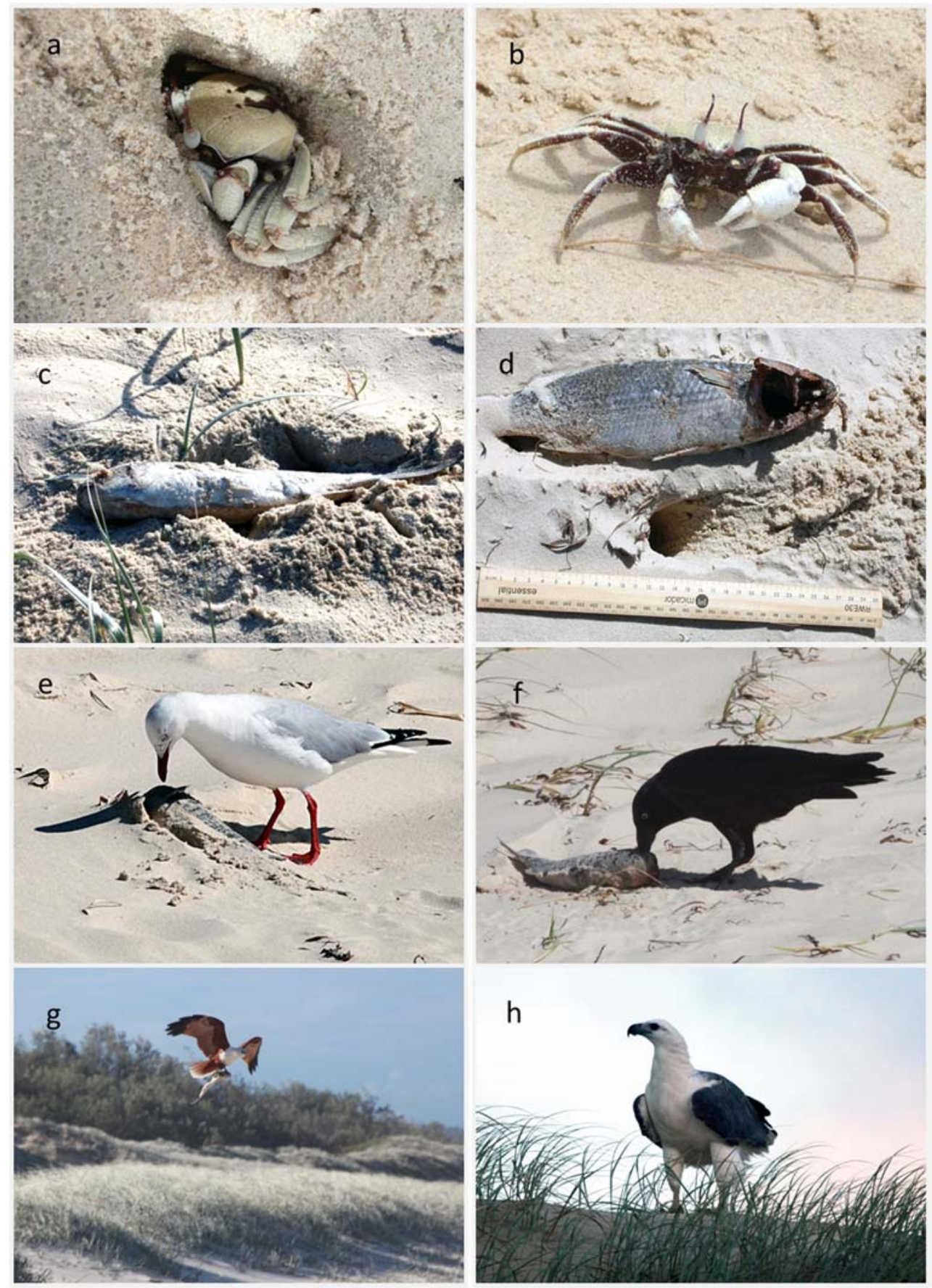

Fig. 3 Ghost crabs and avian scavengers at the beach-dune interface region observed during the study. a) ghost crab (Ocypode ceratophthalma) emerging from a burrow and b) active on the beach surface; c) intense burrowing activity of crabs around and under a freshly deposited fish carcass; d) burrow opening of a ghost crab next to a fish carcass showing freshly excavated sediment; e) Silver gull (Chroicocephalus novaehollandiae) and f) Torresian crow (Corvus orro) feeding on fish carrion; $g$ )

Brahminy kite (Haliastur indus) lifting a fish carcass from an experimental plot; $h$ ) white-bellied sea eagle (Haliaeetus leucogaster) perched on the primary dune above an experimental plot to which fish carcasses had been added. All photos T. A. Schlacher. 


\subsection{Vertebrate scavengers}

In addition to ghost crabs, a number of vertebrate scavengers consumed fish carrion in the experimental plots (Table 2, Fig. 3). We directly observed, or recorded prints of, several species of raptors (whistling kite, Haliastur sphenurus; Brahminy kite, Haliastur indus; white-bellied sea aagle; Haliaeetus leucogaster), pied oystercatchers (Haematopus longirostris) and silver gulls (Chroicocephalus novaehollandiae). Tracks and prints of red foxes (Vulpes vulpes) were common, occurring in most plots on most days (Table 1). These vertebrate scavengers had a major impact on carrion during the experiment, as evidenced by: i) of the 324 pieces of fish added to experimental plots over the course of the experiment, all were consumed; ii) in a single night, on average $80 \%$ of carrion items were removed (s.e. $=20 \%$ ), and iii) in two-thirds of plots where carrion was added at dusk, all carcasses had been consumed by the following dawn. These high carrion consumption rates are most probably the result of scavenging by vertebrates for the following reasons: i) we directly observed avian scavengers feeding on carrion in treatment plots, occasionally lifting entire fish off the beach (Fig. 3), ii) fish were too large for ghost crabs to consume them entirely in a single night, and iii) tracks of red foxes converged on carrion pieces and there were clear signs that they had handled the fish carcasses.

Table 1 Occurrence of vertebrate scavengers in the experimental plots, based on either direct observations or tracks/prints left in the sand. Tabulated values are the number of plots $(\max n=9$ ) with a positive record.

\begin{tabular}{lcccccc} 
Vertebrate Scavenger & Day 2 & Day 4 & Day 5 & Day 6 & Experiment \\
\hline Red fox & 6 & 5 & 6 & 6 & 8 & $(89 \%)$ \\
Pied oystercatchers & 1 & 2 & 6 & 6 & 8 & $(89 \%)$ \\
Silver gulls & 1 & 2 & 4 & 4 & 6 & $(67 \%)$ \\
$\begin{array}{l}\text { Raptors (Brahminy kite, whistling kite, white- } \\
\text { bellied sea eagle) \& crows }\end{array}$ & 2 & 0 & 5 & 4 & 9 & $(100 \%)$ \\
\hline
\end{tabular}

\subsection{Cascading effects}

Vertebrate scavengers modified the numerical response of ghost crab scavengers to enhanced carrion availability (Fig. 4). In experimental plots where raptors, foxes or oystercatchers had been recorded, the abundance of ghost crabs still increased, but by about $20 \%$ less than in plots without these vertebrate scavengers. Higher removal rates of carrion by vertebrate scavengers significantly depressed the aggregative responses of ghost crabs to fish carcasses (Fig. 4).

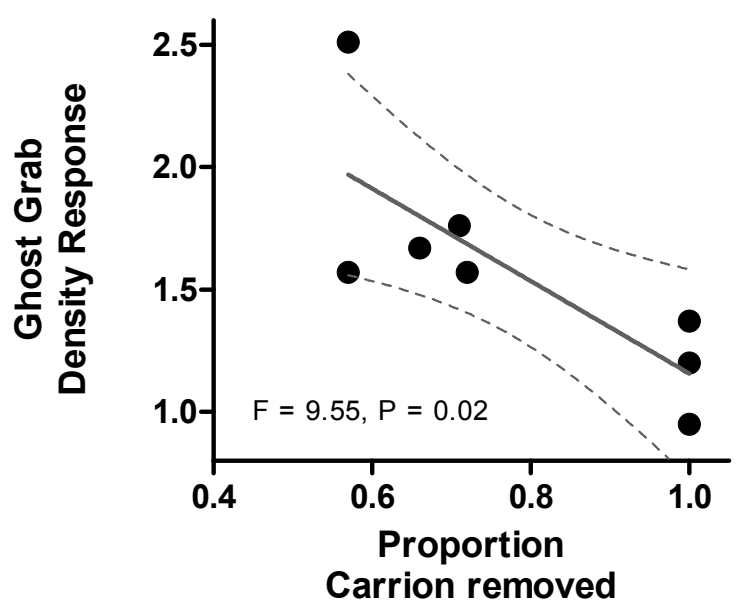

Fig. 4 Numerical response of invertebrate scavengers (ghost crabs) as a function of the proportion of carrion pieces removed by vertebrate scavengers. 
Table 2 Examples of published records of carrion and scavengers on beaches.

\begin{tabular}{|c|c|c|c|}
\hline Scavenger & Carrion type & Location & Reference \\
\hline \multicolumn{4}{|l|}{ Invertebrates } \\
\hline $\begin{array}{l}\text { Whelks (Bullia rhodostoma, } \\
\text { B. digitalis) }\end{array}$ & Cnidarians & Eastern Cape, South Africa & $\begin{array}{l}\text { (Brown 1961; 1971; Brown } \\
\text { 1982) }\end{array}$ \\
\hline Nassarius festivus & Fish carrion & Hong Kong & (Morton and Yuen 2000) \\
\hline Isopods, Polychaetes, Beetles & Various drift carrion & California, USA & (Dugan et al. 2003) \\
\hline Ghost crabs (Ocypode spp.) & Fish and invertebrates & Eastern Australia, global & $\begin{array}{l}\text { This study; } \\
\text { (Cott 1929; Wolcott 1978) }\end{array}$ \\
\hline \multicolumn{4}{|l|}{ Reptiles } \\
\hline $\begin{array}{l}\text { Cottonmouth Snake } \\
\text { (Agkistrodon piscivorus conanti) }\end{array}$ & Various dead fish & Gulf Coast Islands, USA & $\begin{array}{l}\text { (Lillywhite and McCleary } \\
\text { 2008; Lillywhite et al. } \\
\text { 2008) }\end{array}$ \\
\hline \multicolumn{4}{|l|}{ Birds } \\
\hline $\begin{array}{l}\text { White-Bellied Sea Eagle } \\
\text { (Haliaeetus leucogaster) }\end{array}$ & $\begin{array}{l}\text { Various mammals, other } \\
\text { birds, fish, crabs }\end{array}$ & Coastal areas, Australia & (Smith 1985) \\
\hline $\begin{array}{l}\text { Whistling Kite } \\
\text { (Haliastur sphenurus) }\end{array}$ & $\begin{array}{l}\text { Various terrestrial and } \\
\text { marine animals (rodents, } \\
\text { reptiles, fish) }\end{array}$ & Coastal areas, Australia & (Gosper 1983) \\
\hline Brahminy Kite (Haliastur indus) & $\begin{array}{l}\text { Fish, crabs \& other } \\
\text { marine carrion }\end{array}$ & Coastal areas, Australia & $\begin{array}{l}\text { (Smith 1992; Lutter et al. } \\
\text { 2006) }\end{array}$ \\
\hline \multicolumn{4}{|l|}{ Mammals } \\
\hline Coyote (Canis latrans) & $\begin{array}{l}\text { Seals, birds, sea turtles, } \\
\text { fish, marine arthropods }\end{array}$ & California, USA & (Rose and Polis 1998) \\
\hline $\begin{array}{l}\text { Tasmanian Devil } \\
\text { (Sarcophilus harrisii) }\end{array}$ & $\mathrm{N} / \mathrm{A}$ & Tasmania, Australia & (Moore 2002) \\
\hline $\begin{array}{l}\text { Brown Hyena } \\
\text { (Parahyaena brunnea) }\end{array}$ & Seals & Skeleton Coast, Namibia & $\begin{array}{l}\text { (Skinner et al. 1995; Kuhn } \\
\text { et al. 2008) }\end{array}$ \\
\hline $\begin{array}{l}\text { Black-backed Jackal } \\
\text { (Canus mesomelas) }\end{array}$ & Seals, birds, fish & Skeleton Coast, Namibia & (Avery et al. 1987) \\
\hline Dingo (Canis lupus dingo) & $\begin{array}{l}\text { Dugong and whale } \\
\text { carcasses }\end{array}$ & Fraser Island, Australia & (Moore 2002) \\
\hline Lion (Panthera leo) & Seals & Skeleton Coast, Namibia & (Bridgeford 1984) \\
\hline
\end{tabular}

\section{Discussion}

Our experimental augmentation of carrion supply demonstrated bottom-up control of consumers, using scavengers as a model on an ocean-exposed sandy beach. Scavengers are a commonly reported component of beach fauna, encompassing a wide diversity of taxa and broad spectrum of carrion types (Table 2). Yet important functional ecological aspects of scavenging remain to be quantified in beach systems, across four broad thematic areas: i) population and community-wide effects of altered carrion resources, ii) the spatial structure of carrion-based food webs on sedimentary shorelines, iii) properties of resource pulses and their influence on scavenger dynamics, and iv) interactions between scavengers. 
Our experiment showed a clear aggregative response of scavengers to carrion, significantly changing local densities of consumers to create spatial concentrations of intense feeding along the shore. Although the duration of the experiment did not allow us to measure numerical responses in the populations, these are not implausible for the scavengers examined. Enhanced food resources have been shown to have population-wide consequences for consumers on shorelines, positively affecting reproductive output and population sizes in both invertebrate and vertebrate scavengers benefiting from imports of marine matter (Spiller 1992; Rose and Polis 1998; Roth 2003). Because true numerical responses depend mainly on the generation time of the consumers, these would be predicted to occur within months for ghost crabs, but may take years for raptors (Machant and Higgins 1993). Notwithstanding the time scales required, enhancing local populations of scavenging raptors on shorelines with carrion augmentations offers an opportunity to investigate a potentially novel conservation tool for these threatened species (along the lines of augmented feeding of hen harriers, a vulnerable raptor in the United Kingdom, Thompson et al. 2009).

Aggregative responses of scavengers were distinct in the experimental plots. A central goal of ecology is to derive generalizations about processes that are applicable to broader temporal and spatial scales. In this sense, 'scaling-up' from small-scale field experiments to larger areas will be important (sensu Denny and Benedetti-Cecchi 2012). Carrion addition experiments, like the one conducted here, are highly amenable to examine such scale-dependence of ecological processes. At regional scales, the links between scavenger dynamics and their food supply can be determined by manipulating carrion availability among beaches separated sufficiently to avoid mixing of populations (i.e. islands or geographically distant beaches). This approach would also lends itself to a still wider scaleencompassing latitudinal gradients and different biogeographic provinces, to take account of the putative effect of different taxonomic compositions of scavengers.

Carrion removal in our experiment was rapid and efficient, with most fish carcasses having been completely consumed within a day. This high rate of carrion detection and consumption on beaches rivals, or exceeds, that of other habitats (reviewed by DeVault et al. 2003). It demonstrates that scavengers on beaches are highly adapted to exploit resource bounties in the form of pulsed carrion inputs. More generally, pulsed resources have a major influence on consumer dynamics and food webs across many ecosystems (Yang. L.H. 2010). Factors that modify ecological responses to pulsed resources include the quality, quantity, duration and predictability of the inputs (Yang. L.H. 2008). Although it seems logical to posit that carrion constitutes an unpredictable resource pulse on sandy shores, patterns of marine carrion inputs to beach food webs are essentially unknown. Standing stocks of carrion in the size range of fish carcasses are usually low on beaches. This does not necessarily reflect low inputs of carcasses, but, alternatively, could result from rapid location and consumption of carcasses by efficient scavengers as shown here (see also Rassweiler and Rassweiler 2011).

Ghost crabs aggregated in significantly lower numbers in experimental plots where more intense scavenging activity by birds and foxes had removed more carrion (Fig. 4). This negative relationship between one consumer's response as a function of another consumer's use of a common resource strongly suggests asymmetrical biological interactions between invertebrate and vertebrate scavengers. There are several, interrelated mechanisms that are plausible to explain the observed relationship between smaller aggregative responses of ghost crabs in situations when vertebrate scavengers had removed more of the available carrion: 1.) competition for carrion, resulting in lower food availability to ghost crabs due to removal of carcasses by the competitively dominant vertebrate scavengers, 2.) lower foraging activity of ghost crabs when vertebrate scavengers are more abundant or active, due to higher predation risk for crabs - a trait-mediated effect (sensu Werner and Peacor 2003), and/or 3.) predation by birds and foxes of ghost crabs that had aggregated around fish carcasses. Carrion falls and scavengers can profoundly influence predator-prey dynamics and competition (Abrams et al. 1998; Cortés-Avizanda et al. 2009; Berger 2010). Because ghost crabs are 
prey for birds on beaches (Schlacher pers. obs.) and vertebrates remove large amounts of carrion, each of the three mechanisms - competition, trait-mediated effects, predation - can operate in this food web. Future experiments that distinguish between multiple biological interactions and determine their interaction strengths in these food webs will be important to determine the structure and dynamics of scavenging food webs at the beach-dune interface.

\section{Acknowledgements}

A warm "Thank YOU" to Tara Nielsen and Sam Masters for their unfaltering assistance in the field, showing steely resolve before the enemy 'mullet odour': you never made a ghost of crabs.

\section{References cited}

Abrams, P.A., Holt, R.D., Roth, J.D. (1998) Apparent competition or apparent mutualism? Shared predation when populations cycle. Ecology, 79(1), 201-212.

Avery, G., Avery, D.M., Braine, S., Loutit, R. (1987) Prey of coastal black-backed jackal Canis mesomelas (Mammalia: Canidae) in the Skeleton Coast Park, Namibia. Journal of Zoology, 213(1), 81-94.

Barreiro, F., Gómez, M., Lastra, M., López, J., De la Huz, R. (2011) Annual cycle of wrack supply to sandy beaches: effect of the physical environment. Marine Ecology Progress Series, 433, 65-74.

Barrett, K., Anderson, W.B., Wait, D.A., Grismer, L.L., Polis, G.A., Rose, M.D. (2005) Marine subsidies alter the diet and abundance of insular and coastal lizard populations. OIKOS 109, 145-153.

Bascom, W. (1980). Waves and beaches: the dynamics of the ocean surface. Anchor Press, Garden City, New York: 366 pp.

Beasley, J.C., Olson, Z.H., Devault, T.L. (2012) Carrion cycling in food webs: Comparisons among terrestrial and marine ecosystems. Oikos, 121(7), 1021-1026.

Berger, J. (2010) Fear-mediated food webs. In: J. Terborgh \& J.A. Estes (Eds). Trophic cascades: Predators, prey, and the changing dynamics of nature. Island Press, Washington, DC: 241-254.

Bridgeford, P.A. (1984) Unusual diet of the lion Panthera leo in the Skeleton Coast Park, Namibia. Madoqua, 14, 187-188.

Brown, A.C. (1961) Physiological-ecological studies on two sandy-beach gastropoda from South Africa: Bullia digitalis; meuschen and Bullia laevissima (gmelin). Zoomorphology, 49(6), 629-657.

Brown, A.C. (1971) The ecology of sandy beaches of the Cape Peninsula, South Africa. Part 1: Introduction. Transactions of the Royal Society of South Africa, 39(3), 247-279.

Brown, A.C. (1982) The biology of sandy-beach whelks of the genus Bullia (Nassariidae). Oceanography and Marine Biology, Annual Review, 20, 833.

Brown, A.C. (1982) The Biology of Sandy-Beach Whelks of the genus Bullia (Nassariidae). In: H. Barnes \& M. Barnes (Eds). Oceanography and Marine Biology: An Annual Review. Aberdeen University Press: 309-361.

Colombini, I., Chelazzi, L. (2003) Influence of marine allochthonous input on sandy beach communities.

Oceanography and Marine Biology. An Annual Review, 41, 115-159. 
Cortés-Avizanda, A., Selva, N., Carrete, M., Donázar, J.A. (2009) Effects of carrion resources on herbivore spatial distribution are mediated by facultative scavengers. Basic and Applied Ecology, 10(3), 265-272.

Cott, H. (1929) Observations on the natural history of the racing-crab Ocypode ceratophthalma from Beira. Proceedings of the Zoological Society of London, 1929, 755-765.

Denny, M.W., Benedetti-Cecchi, L. (2012) Scaling up in ecology: mechanistic approaches. Annual Review of Ecology, Evolution, and Systematics, 43(1).

DeVault, T.L., Rhodes Jr, O.E., Shivik, J.A. (2003) Scavenging by vertebrates: Behavioral, ecological, and evolutionary perspectives on an important energy transfer pathway in terrestrial ecosystems. Oikos, 102(2), 225 234.

Dugan, J.E., Hubbard, D.M., McCrary, M.D., Pierson, M.O. (2003) The response of macrofauna communities and shorebirds to macrophyte wrack subsidies on exposed sandy beaches of southern California. Estuarine, Coastal and Shelf Science, 58(Suppl S), 25-40.

Dugan, J.E., Hubbard, D.M., Page, H.M., Schimel, J.P. (2011) Marine macrophyte wrack inputs and dissolved nutrients in beach sands. Estuaries and Coasts, 1-12.

Gosper, D.J. (1983) Birds in the Richmond River district, NSW. Corella(7), 7-13.

Heymans, J.J., McLachlan, A. (1996) Carbon budget and network analysis of a high-energy beach/surf-zone ecosystem. Estuarine, Coastal and Shelf Science, 43(4), 485-505.

Houston, D.C. (1979) The adaptation of scavengers. In: A.R.E. Sinclair \& M. Norton- Griffiths (Eds).

Serengeti: Dynamics of an Ecosystem. University of Chicago Press, Chicago: 263-286.

Kuhn, B.F., Wiesel, I., Skinner, J.D. (2008) Diet of brown hyaenas (Parahyaena brunnea) on the Namibian coast. Transactions of the Royal Society of South Africa, 63(2), 150-159.

Lillywhite, McCleary (2008) Trophic ecology of insular cottonmouth snakes: Review and perspective. South American Journal of Herpetology(3), 175-185.

Lillywhite, H.B., Sheehy, C.M., Zaidan, F. (2008) Pitviper scavenging at the intertidal zone: An evolutionary scenario for invasion of the sea. BioScience, 58(10), 947-955.

Lutter, H., McGrath, M., McGrath, M., Debus, S. (2006) Observations on nesting brahminy kites Haliastur indus in Northern New South Wales. Australian Field Ornithology, 23(4), 177.

Machant, S., Higgins, P.J. (1993). Handbook of Australian, New Zealand and Antarctic Birds, Volume 2 (Raptors to Lapwings). Oxford University Press, Melbourne.

MacMillan, M.R., Quijon, P.A. (2012) Wrack patches and their influence on upper-shore macrofaunal abundance in an Atlantic Canada sandy beach system. Journal of Sea Research, 72, 28-37.

McLachlan, A. (1991) Ecology of coastal dune fauna. Journal of Arid Environments, 21.

McLachlan, A., Brown, A.C. (2006). The ecology of sandy shores. Academic press, Burlington, Massachusetts.

Mellbrand, K., Lavery, P.S., Hyndes, G., Hambäck, P.A. (2011) Linking Land and Sea: Different Pathways for Marine Subsidies. Ecosystems, 14(5), 732-744. 
Moore, P.G. (2002) Mammals in intertidal and maritime ecosystems: Interactions, impacts and implications. Oceanography and Marine Biology, 40, 491-608.

Morton, B., Yuen, W.Y. (2000) The feeding behaviour and competition for carrion between two sympatric scavengers on a sandy shore in Hong Kong: The gastropod, Nassarius festivus (Powys) and the hermit crab, Diogenes edwardsii (De Haan). Journal of Experimental Marine Biology and Ecology, 246(1), 1-29.

Noriega, R., Schlacher, T.A., Smeuninx, B. (2012) Reductions in ghost crab populations reflect urbanization of beaches and dunes. Journal of Coastal Research, 28(1), 123-131.

Orr, M., Zimmer, M., Jelinski, D.E., Mews, M. (2005) Wrack deposition on different beach types: Spatial and temporal variation in the pattern of subsidy. Ecology, 86(6), 1496-1507.

Polis, G.A., Anderson, W.B., Holt, R.D. (1997) Toward an integration of landscape and food web ecology: The dynamics of spatially subsidized food webs. Annual Review of Ecology and Systematics, 28, 289-316.

Rassweiler, A., Rassweiler, T. (2011) Does rapid scavenging hide non-predation mortality in coral-reef communities? Marine and Freshwater Research, 62(5), 510-515.

Rose, M.D., Polis, G.A. (1998) The distribution and abundance of coyotes: The effects of allochthonous food subsidies from the sea. Ecology, 79(3), 998-1007.

Roth, J.D. (2003) Variability in marine resources affects arctic fox population dynamics. Journal of Animal Ecology, 72(4), 668-676.

Ruxton, G.D., Houston, D.C. (2004) Obligate vertebrate scavengers must be large soaring fliers. Journal of Theoretical Biology, 228(3), 431-436.

Sanchez-Pinero, F., Polis, G.A. (2000) Bottom-Up dynamics of allochthonous input: direct and indirect effects of seabirds on islands. Ecology, 81(11), 3117-3132.

Schlacher, T.A., Connolly, R.M. (2009) Land-ocean coupling of carbon and nitrogen fluxes on sandy beaches. Ecosystems, 12(2), 311-321.

Schlacher, T.A., de Jager, R., Nielsen, T. (2011) Vegetation and ghost crabs in coastal dunes as indicators of putative stressors from tourism. Ecological Indicators, 11, 284-294.

Schlacher, T.A., Lucrezi, S. (2010) Experimental evidence that vehicle traffic changes burrow architecture and reduces population density of ghost crabs on sandy beaches. Vie Et Milieu-Life and Environment, 60(4), 313320.

Schlacher, T.A., Lucrezi, S. (2010) Experimental evidence that vehicle traffic changes burrow architecture and reduces population density of ghost crabs on sandy beaches. Vie Et Milieu 60(4), 313-320.

Schlacher, T.A., Richardson, D., McLean, I. (2008) Impacts of off-road vehicles (ORVs) on macrobenthic assemblages on sandy beaches. Environmental Management, 41, 878-892.

Schlacher, T.A., Schoeman, D.S., Dugan, J.E., Lastra, M., Jones, A., Scapini, F., McLachlan, A. (2008) Sandy beach ecosystems: key features, sampling issues, management challenges and climate change impacts. Marine Ecology - Evolutionary Perspective, 29 (S1), 70-90.

Schlacher, T.A., Thompson, L.M.C. (2007) Exposure of fauna to off-road vehicle (ORV) traffic on sandy beaches. Coastal Management, 35, 567-583. 
Schlacher, T.A., Thompson, L.M.C. (2008) Physical impacts caused by off-road vehicles (ORVs) to sandy beaches: spatial quantification of car tracks on an Australian barrier island. Journal of Coastal Research, 224, 234-242.

Schlacher, T.A., Thompson, L.M.C., Price, S. (2007) Vehicles versus conservation of invertebrates on sandy beaches: quantifying direct mortalities inflicted by off-road vehicles (ORVs) on ghost crabs. Marine Ecology Evolutionary Perspective, 28, 354-367.

Skinner, J.D., Van Aarde, R.J., Goss, R.A. (1995) Space and resource use by brown hyenas (Hyaena brunnea) in the Namib Desert. Journal of Zoology, 237, 123-131.

Smith, G.C. (1985) An analysis of prey remnants from Osprey (Pandion haliaetus) and White-Bellied sea eagle (Haliaetus leucogaster) feeding roosts. Emu, 85, 198.

Smith, J.I.D. (1992) The feeding ecology of brahminy kites, Haliastur indus from South-east Queensland. $\mathrm{BSc}(\mathrm{Hons})$ thesis. University of Queensland, Brisbane, Australia.

Spiller, D.A. (1992) Numerical response to prey abundance by Zygiella $x$-notata (Araneae, Araneidae). Journal of Arachnology, 20(3), 179-188.

Spiller, D.A., Piovia-Scott, J., Wright, A.N., Yang, L.H., Takimoto, G., Schoener, T.W., Iwata, T. (2010) Marine subsidies have multiple effects on coastal food webs. Ecology, 91(5), 1424-1434.

Walker, S.J., Schlacher, T.A. (2011) Impact of a pulse human disturbance experiment on macrofaunal assemblages on an Australian sandy beach. Journal of Coastal Research, 27(6A), 184-192.

Werner, E.E., Peacor, S.D. (2003) A review of trait-mediated indirect interactions in ecological communities. Ecology, 84(5), 1083-1100.

Wilson, E.E., Wolkovich, E.M. (2011) Scavenging: How carnivores and carrion structure communities. Trends in Ecology and Evolution, 26(3), 129-135.

Wolcott, T.G. (1978) Ecological role of ghost crabs, Ocypode quadrata (Fab.) on an ocean beach: scavengers or predators? Journal of Experimental Marine Biology \& Ecology, 31, 67-82.

Wright, L.D., Short, A.D. (1984) Morphodynamics variability of surf zones and beaches: A synthesis. Marine Geology, 56, 93-118.

Yang. L.H., E.K.F., Byrnes. J, Bastow. J.L., Wright A.N, Spence. K.O (2008) What can we learn from resource pulses? Ecological Society of America, 89, 621-634.

Yang. L.H., E.K.F., Byrnes. J, Bastow. J.L., Wright A.N, Spence. K.O (2010) A meta-analysis of resource pulse-consumer interactions. Ecological Monographs by the Ecological Society of America, 80(1), 125-151. 